\title{
Building the Character and Thought Structure of Political Actors based on Pancasila Politics
}

\author{
Ruhadi $^{1}$, Giri Harto Wiratomo² \\ Program Studi Pendidikan Pancasila dan Kewarganegaraan Jurusan Politik dan \\ Kewarganegaraan Fakultas IImu Sosial-Universitas Negeri Semarang ${ }^{1,2}$ \\ ruhadi@mail.unnes.ac.id/ruhadi_h@yahoo.co.id ${ }^{1}$, girihw@mail.unnes.ac.id²
}

\section{Article History}

accepted 24/03/2021

approved 10/04/2021

published 20/04/2021

\begin{abstract}
The development of a negative stigma against politics today is a reality that occurs in the mindset of society. This is caused by various factors including the thoughts, attitudes, and behavior of political actors. One of them is a politician. The thoughts, attitudes, and behavior of politicians have a significant role in shaping the image of politics in the eyes of society. Currently, there is a lot of negative stigma about politics. There are two theories in politics, namely moral based theories and political theories that ignore the moral conflict between these two theories and there is a tug of war in the current political field in politicians so that two problems are related to the background of the basic thought structure of politicians who are driven to practice praxis. negative politics and efforts to form a political thought structure that is in line with the "Political Value" of the Indonesian nation are interesting issues to study. The method used in this paper is a qualitative approach with the literary study method, based approach, it can be seen that the theories currently developing are political theories that ignore the moral basis and requirements with pragmatism in politics so that it requires the strengthening and construction of the Pancasila political building which is prerequisite. with immorality to displace political theories that are far from moral bases and to eradicate various immoral behavior of politicians today.
\end{abstract}

keywords: character building, politicians, Pancasila politics

\begin{abstract}
Abstrak
Berkembangnya stigma negatif terhadap politik saat ini merupakan realitas yang terjadi di tengah-tengah masyarakat tidak dapat dipungkiri. Hal ini disebabkan oleh berbagai faktor diantaranya adalah pemikiran, sikap dan prilaku para actor politik. Salah satu diantaranya adalah politisi. Pemikiran, sikap dan perilaku para politisi memiliki peran yang cukup besar dalam membentuk kesan politik di mata masyarakat. Saat ini berkembang banyak stigma negatif tentang politik. Pada dasarnya terdapat dua teori dalam politik yaitu teori-teori politik yang berdasarkan moral dan teori-teori politik yang mengabaikan moral pertentangan dua teori ini terjadi tarik ulur di lapanga politik saat ini dalam diri politisi sehingga dua permasalahan terkait latar belakang struktur pemikiran mendasar dari politisi yang terdorong untuk melakukan praksis politik negatif dan upaya membentuk struktur pemikiran politisi yang sesuai "Political Value" bangsa Indonesia menjadi persoalan menarik untuk dikaji. Metode yang digunakan dalam penulisan ini adalah pendekatan kulitatif dengan metode studi literatur, berdasarkan pada pendekatan ini maka dapat diketahui bahwa teori-teori yang berkembang saat ini adalah teori-teori politik yang mengabaikan dasar moral dan syarat dengan pragmatisme dalam berpolitik sehingga membutuhkan penguatan dan konstruksi banguan politik Pancasila yag syarat dengan niai moral untuk menggusur teori-teori politik yang jauh dari dasar moral dan menangkal berbagai perilaku amoral para politisi saat ini

Kata kunci: membangun karakter, politisi, politik Pancasila
\end{abstract}

Social, Humanities, and Education Studies (SHEs): Conference Series https://jurnal.uns.ac.id/shes

p-ISSN 2620-9284 e-ISSN 2620-9292 


\section{PENDAHULUAN}

Berkembangnya stigma negatif terhadap politik saat ini merupakan realitas yang terjadi di tengah-tengah masyarakat tidak dapat dipungkiri. Hal ini disebabkan oleh berbagai factor diantaranya adalah pemikiran, sikap dan prilaku para aktor politik. Salah satu diantaranya adalah politisi. Pemikiran, sikap dan prilaku para politisi memiliki peran yang cukup besar dalam membentuk kesan politik di mata masyarakat. Saat ini berkembang banyak stigma negatif tentang politik. Berbagai stigma negatif itu antara lain dinyatakannya bahwa politik itu kotor, politik tempatnya orang berbohong, tidak ada kawan sejati dalam politik yang ada lawan bisa menjadi kawan yang kawan bisa berubah menjadi lawan,politik menjadikan orang menghalalkan segala cara dalam meraih kekuasaan. Ungkapan dan realitas yang terjadi menjadi potongan pengetahuan dan pembuktian yang ada dimasyarakat, ketika ungkapan-ungkapan itu menjadi realita. Maka pernyataan dan pembenaran fakta ini seperti menjadi sesuatu ajaran yang diyakini melebihi teori apapun dan sulit dilepaskan dari pemikiran masyarakat dan para politisi. Struktur pemikiran seperti ini akan menjadi tragedi pemikiran berkepanjangan dari generasi-ke generasi, dari satu decade politik ke dekade politik berikutnya,. Apabila tidak terdapat gerakan pembaharuan terutama oleh para politisi.

Sesungguhnya bangsa ini memiliki nilai-nilai yang adi luhur dan berbasis pada kearifan lokal Nusantara dan menjadi puncak dari pemikiran peradaban bangsa Indonesia yaitu Nilai-nilai Pancasila.Teori-teori politik, pengaruh berbagai tekanan, paham, ajaran,organisasi dari berbagai belahan dunia dan faktor dari dalam negeri mengisi pemikiran-pemikiran para politisi bangsa sehingga mereka banyak yang berpikir, bersikap dan bertindak sesuai dengan teori-teori politik yang mereka dewakan, kepentingan-kepentingan yang mereka harapkan, serta misi dan ambisi yang mereka menjadikan negara kita tercabut dari nilai yang adi luhur yaitu Pancasila. Oleh karena itu tulisan ini bertujuan untuk mengajarkan dan mengembalikan politik kepada fitrohnya sebagai ilmu yang tidak semata-mata mengandalkan logika dan sifat ilmiah tetapi juga mengedepankan nilai dan moral berdasarkan Politik Pancasila bagi para politisi sehingga mampu mengubah wajah politik menjadi bidang dari bagian kehidupan manusia kearah kesejahteraan lahir dan batin.

Politik secara diamental politik dibedakan menjadi dua yaitu "political value" dan "political action"menurutnya politik sebagai nilai berbasis pada konsep dan kebiasaan kebiasan serta iman transendental masyarakat setempat. Politik sebagai nilai berbasis pada teori dan konsep, berakar pada pengetahuan dan tentu saja memiliki sejarah yang terikat dengan nilai yang dianut oleh sebuah masyarakat.sedangkan politik sebagai "political action" Sedangkan politik sebagai tindakan menurut penulis berprinsip pada realitas, pada kenyataan-kenyataan yang terjadi, ia lebih pragmatis, taktis dan berjangka pendek. Pada situasi tertentu diperlukan kemampuan menjalankan politik praktis ini secara cerdas dengan tetap berpedoman pada nilai-nilai yang dianut oleh masyarakat. Sehingga tampak bahwa politik sebagai tindakan adalah berhubungan dengan sikap jangka pendek pendapat/pandangan.Berdasarkan pembedaan politik secara diamental di atas maka dapat dikemukakan bahwa secara "political value" bahwa kerangka darisegala aktivitas penyelenggaraan politik di Indonesia di dasarkan pada nilai yang berbasis Pada Pancasila. Nilai-nilai Pancasila berakah dari factor historis, factor kultral filosofis dan yuridis bangsa Indonesia.Nilainilai dalam Pancasila syarat dengan nilai-nilai moral, syarat dengan nilai-nilai kemanusiaan, syarat nilai-nilai persatuan dan syarat dengan nilai-nilai kerakyatan yang akan membawa pada manusia Indonesia sejahtera lahir dan Batin. Pancasila menjadi pedoman bagi bangsa Indonesia dalam berbagai bidang kehidupan termasuk dalam kehidupan politik.Pancasila penuh dengan muatan nilai-nilai yang mampu mengangakat harkat dan artabat manusia Indonesia sebagi bagian dari masyarakat dunia, apabila dalam berpolitik mampu menimpemntasikan dari "Political Value " yang telah dimilki bangsa Indonesia maka realitas politik seharusnya menjadi bidang 
kehidupan yang positif untuk membangun bangsa. Tetapi yang menjadi persoalan adalah adanya kesenjangan yang cukup jauh antara "Political Value" dan "Political Action" di Indonesia, apa yang dipraktikkan tidak sesuai dengan dunia nilai yang sudah dirumuskan, terutama para politisi dalam menjalankan peran politiknya. "action" para politisi mengingkari atauberjalan berlawanan dengan konsep "Value"bangsa Indonesia. Apa yang dlakukan politisimejadi sorotan, menjadi focus perhatian dan menjadi eladhanserta contoh bagi masyarakatnya, sehigga terjadi gerak berbanding terbalik atara "Politcal Value" bangsa Indonesia dengan "political Action" banyak politisi yang melakukan peran terjun bebas mengerus nilai-nilai etika politik Pancasila sehingga citra dan pemaknaan politik menjadi kearah pemaknaan yang negatif jauh dari hakikat ilmu politik itu sendiri. Banyak sekali para politisi yang terjerat dalam kasus korupsi, janji palsu dalamkampanye, kecurangan,money politik,maneuver kepentingan untuk kelompok dan pribadinya, jalan pintas, mengingkari kesepakatn-kesepakatan politis dan berbagai pelanggaran nilainya menjadikan politik seperti semakin berhadapan dan berdiri jauh darikonsep nilai bangsa Indonesia yang penuh dengan keluhuran.

Berdasarkan paparandi atas maka terdapat suatu permasalahan yang cukup menarik untuk kita bahas dalam pembahasan tulisan ini.1.Bagaimana latar belakang struktur pemikiran mendasar dari politisi yang terdorong untuk melakukan praksis politik negatif ?, 2.Bagaimana upaya membentuk struktur pemikiran politisi yang sesuai "Political Value"bangsa Indonesia?

Dengan upaya membangun kembalikerangka berpikir dan memulihkan strktur berpikir berdasarkan konsep nilai politik Pancasila maka diharapkan akan memperkecil jarak antara "Political Value" dan "Political Action" apa yang dilakukan oleh para politisimenjadiberbanding lurus terhadap konsep nilai Pancasila, sehingga mewujudkan suatu tatanan kesejahteraan yang dicita-citakan bangsa Indonesia.

\section{Teori}

Thomas $\mathrm{P}$. Jenkin membedakan teori politik menjadi dua yaitu pertama,teori politik yang mempunyai dasar moral atau bersifat akhlak dan yang menentukan normanorma untuk perilaku politik, dan yang kedua, teori-teori yang menggambarkan dan membahas fenomena dan fakta-fakta politik dengan tidak mempersoalkan normanorma atau nilai.penggunaan dua teori cukup menarik untuk menganalisis cara berpikir, cara bersikap dan bertindak yang ditampakkan dalam mejalankan kiprah politik di Indonesia.Latar belakang empiris,pendidikan dan teori-teori serta pengetahuan tentang politik akan memilikipengaruh yang cukup besar terhadap perwujudan kiprah politik para politisi.Maka dari itu bagaimana struktur dan cara pemikiran para politisi Indonesia saat ini sehingga membawa pada sebuah pemaknaan politik yang dianggap buruk oleh masyarakat.

Dalam hal ini penulis berasumsi bahwa teori-teori, atau pegetahuan,konsdisi yng diciptakan, lingkungan, pencapaian kepentingan yang ada sedang berlangsung di Indonesia saat ini tidak terlepas daripengaruh teori-teori politik yag mempunyai dasar moral yang dijadikan kiblat para politisi.Asumsi ini didasarkaan pada realita ditemukan berbagai fakta negatif dari prilaku para politisi yang terbukti secara hukum melakukan pelanggaran moralyang jauh dari konsepsi politik Pancasila. Sehingga mengingat cakupan dalam fokus penulisan ini untuk mendapat kesimpulan dari asumsi yang kami ajuan maka metodologi penelitian kualitatif menjdi sangat tepat dalam mencapai dan membuktikan asumsi serta teori yang kami terapkan.

\section{METODE}

Jenis daripenelitian ini menggunakan studi literatur Metode studi literatur adalah serangkaian kegiatan yang berkenaan dengan metode pengumpulan data pustaka, membaca dan mencatat, serta mengelolah bahan penelitian (Zed, 2008:3). Studi kepustakaan merupakan kegiatan yang diwajibkan dalam penelitian, khususnya penelitian akademik yang tujuan utamanya adalah mengembangkan aspek teoritis maupun aspek manfaat praktis. Studi kepustakaan dilakukan oleh setiap peneliti 
dengan tujuan utama yaitu mencari dasar pijakan / fondasi utnuk memperoleh dan membangun landasan teori, kerangka berpikir, dan menentukandugaan sementara atau disebut juga dengan hipotesis penelitian. Sehingga para penelitidapat menggelompokkan, mengalokasikan mengorganisasikan, dan menggunakan variasi pustaka dalam bidangnya. Dengan melakukan studi kepustakaan, para peneliti mempunyai pendalaman yang lebih luas dan mendalam terhadap masalah yang hendak diteliti.

Penggunaan metode ini menjadi lebih untuk mendapatkan pembuktianpembuktian dengan cukup mengamati, mencari sumber-sumber berita terkait prilaku politisi, dari berbagai artikel,jurnal, data di buku, web dan sumber lainnya yang terkait dengan kiprah politisi. Dengan mengumbpulkan berbagai keterangan dari berbagai sumber yang dapat dibuktikan secara logis dan ilmiah cukup untukmenarik sebuah simpulan yang dapat menggambarkan kondisi kiprah politisi di ranah "Political action" . Secara sistematis langkah-langkah penelitian dapat dijelaskan melalui bagan berikut ;
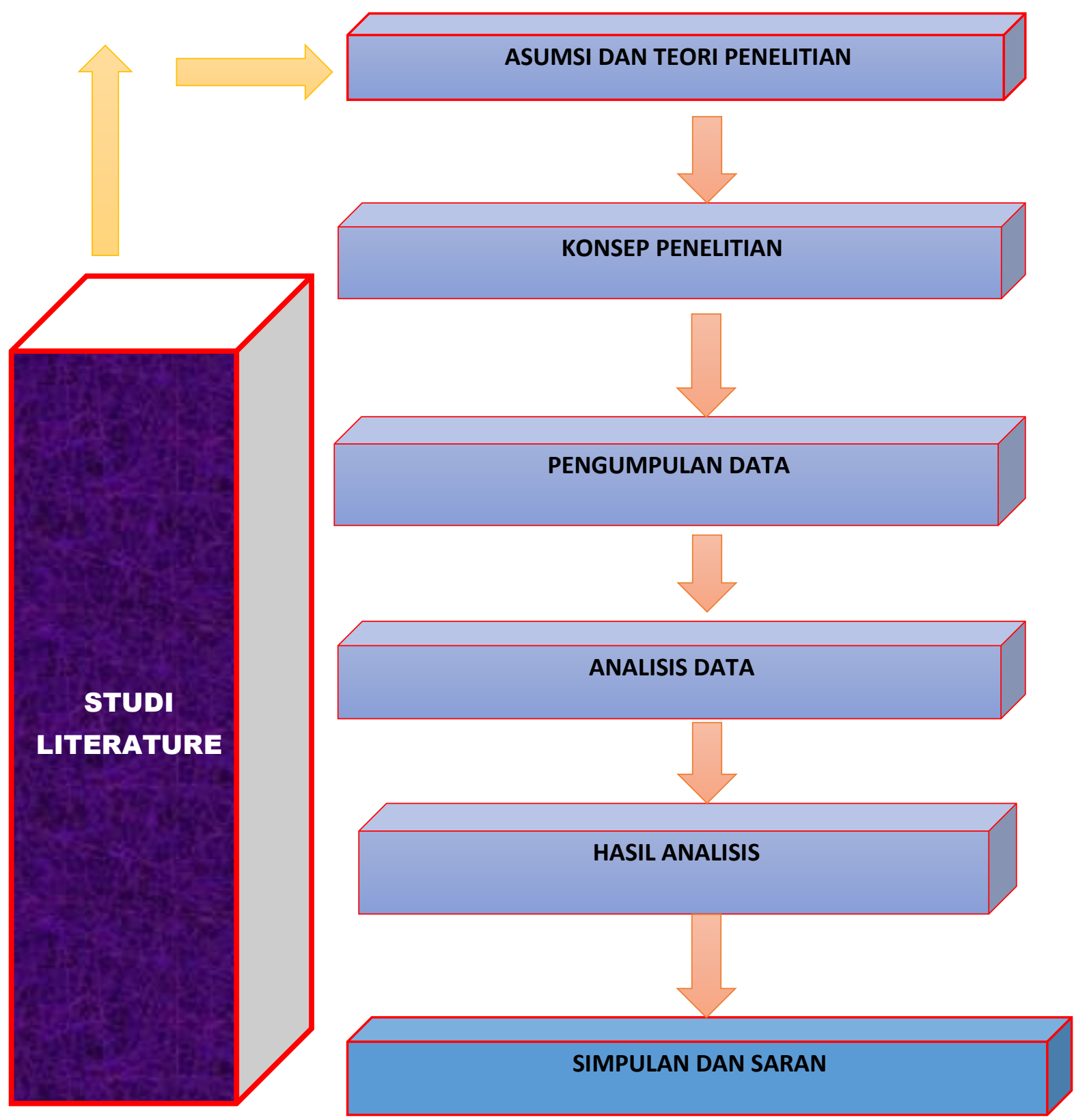

Gambar 1 Alur Penelitian 


\section{HASIL DAN PEMBAHASAN \\ A. Latar Belakang Struktur Pemikiran Mendasar Dari Politisi Yang Terdorong Untuk Melakukan Penyimpangan Politik Pancasila.}

Struktur pemikiran seseorang akan dipengaruhi oleh berbagai factor, latar belakang pendidikan,latar belakang ekonomi latar belakang pendidikan, latar belakang sosial dan budaya, dalam struktur politisi bangsa Indonesia terutama terkait dengan pergerakan politik sejak zaman kolonial selalu di dominasi oleh kaum terdidik, pergerakan politik dan kiprah politisi pada zaman kolonial diwarnai oleh suatu kiprah politik yang cukup kental dengan nuansa nilai yag masih berakar dari budaya bangsa. Sosok Soekarno dapat dijuluki sebagai seorang politisi nasionalis Indonesia dalam memperjuangakan kemerdekaan "Political of Independence". Saudara dapat lihat pemikiran-pemikiran tajam presiden Soekarno dalam pidatopidato diliputi pemikiran berbagai teori politik barat atau teori-teori popular saat itu dan berbagai pemikira-pemikiran yang diwarnai oleh teori-teoriyang berdasarkan fakta-fakta politis. Atau menurut Thomas P. Jenkin, banyak teori-teori yang termasuk dalam teori tidak mempersoalkan norma-norma atau nilai.penggunaan.

Teori-tori politik yang tidak mengindahkan nilai-nilai atau norma bertumpu pada fakta-fakta dan realita yang terjadi.teori ini tidak memepedulikan baik dan buruk tetapi mencoba untuk menjabarkan secara ilmiah. Meskipun dalam strktur pemikiran politik yang ada di dalam diri Soekarno diliputi oleh berbagai teori-teori politik dari Barat tetapi Presiden Soekarno mampu muncul dengan jiwa nasionalisme yang orisinil dan dilandasi oleh Konsepsi Politik Pancasila yang bersumber dari nilai-nilai luhur bangsa.Para kaum pergerakan politik kemerdekaan pada saat itu memiliki konsepsi nilai yang bertumpu pada kearifan-kearifan lokal dan budaya bangsa yang adi luhung,meskipun mereka mempelajari teori-teori politik yang bertumpu pada fakta-fakta politis.

Perubahan zaman didikuti oleh situasi dan kondisi politik yang terus berkembang, sehingga teori-teori politik bergerak mempengaruhi dan dipengaruhi oleh daya nalar dan tindakan serta fakta-fakta seseorang dalam menjalankan kiprah politik. Masyarakat menuju pada kehidupan modern dan terus bergerak menuju sebuah era yang sekarang dikenal dengan era disrupsi, Pada saat ini mobiltas dan jangkauan pergaulan dunia semakin luas dan tempo yang semakin cepat, hal ini berpengaruh juga terhadap prilaku politisi. Banyak sekali teori-teori politik yang tidak mengindahkan tentang norma dan nilai merasuki atau mewarnai setruktur pemikiran dari politisi kita, pragmatisme mendorong politisi cenderung bergerak mewujudkan fakta dari prediktif teori-teori politik yang acuh terhadap norma dan nilai.Pragmatisme berpolitik mendorog seseorang politisi untuk bergerak dalam pencapaian tujuan dengan menghalalkan segala cara, pemikiran-pemikiran liar dan radikal menginjak norma dan nilai yang dijunjung tinggi oleh bangsa dan negara.

Politisi masuk dalam realitas politik yang berpihak pada teori-teori politik yang tidak mengidahkan akhlak, dan menjadi pelukis dominan terhadap wajah politik di Indonesia sehingga politik semakin berkonotasi negatif.Maka dalam implemantatifnya teori-teori politik yang mempunyai dasar moral dan teori-teori politik yang mengabaikan dasar-dasar moral akan melakukan tarik ulur bergerak diantara "Political Value" dan "Political Action".Berdasarkan penegelompokkan teori politik di atas maka. Dapat dijelaskan bahwa tarikan"political action" saat ini lebih kuat dibandingkan dengan konsepsi politik berdasrkan nilai. Sehinga saat ini,politisi banyak yang terjebak dalam tujuan-tujuan jangka pendek yang tidak sesuai dengan konsepsi politik Pancasila yang syarat dengan nilai dan moral.

Teori-teori politik yang tiak didasari pada moralitas atau yang lebih mengedepankan fakta dan realita politik saat ini diakui atau tidak, politik yang 
digandrungidan megisi pikiran dan struktur pemahaman politik para politisi adalah teori-teori yang mengabaikan moral sehingga realitas yang terjadi membawa dampak panapemaknaan politik secara negatif.realitas para politisi yang melakukan korupsi bisa kita amati di Indonesia seperti apa statistiknya. Dari tahun 20042019 ,kepala daerah sebagai pemegang kekuasaan di daerah yang terjerat korupsi mencapai 114 kepala daerah. Sedangkan politisiyang terjerat korupsi dari tahun 2004-2020 terdapat 397kasus "Korupsi yang ditangani KPK 36 persen atau 397 perkara, itu adalah melibatkan pejabat politik. Anggota DPR/DPRD 257, wali kota/bupati 119, ini sampai Mei 2020," kata Giri dalam sebuah webinar yang disiarkan akun Youtube Kanal KPK, Rabu (30/9/2020). berdasarkan data Indonesia Corruption Watch yang menggabungkan jumlah kasus yang ditangani KPK, Kejaksaan dan Kepolisian, ada 253 kepala daerah dan 503 anggota DPR/DPRD yang menjadi tersangka korupsi. Selain itu, data KPK juga menunjukkan bahwa kasus korupsi telah terjadi di 27 dari 34 provinsi se-Indonesia selama 20042020.(kompas.com 2004)

Fakta di atas menjadi sebuah gambaran tentang Political action yang menyimpang dari konsepsi politik yang mendasarkan pada moralitas manusia. Dapat digaris bawahi teori-teori politik yang mengabaikan moral saat ini menjadi sebuah bangunan teori-teori politik yang dianut oleh para politisi saat ini. Teori -teori plitik yang didasarkan pada fakta-fakta politis dan mengabaikan pada dasar moral mendapatkan tempat yang lebih subur struktur pemikiran para politisi bangunan poitik yang membentuk para politisi akan mengarah pada suatu pemikiran politis yang lebih pada pragmatisme dan tujuan jangka pendek meskiupun harus mengindahkan moralitas.dengan demikian teori-teori politikyang mengindahkan atau mengabaikan dasarmoral saat ini menjadi isi dari gelas bening yang ada di dalameikiran para politisi, pada akhirnya mendorong adanya sikap dan prilaku amoral dalamberpolitik.

B. Upaya Membentuk Struktur Pemikiran Politisi Yang Sesuai "Political Value"Bangsa Indonesia

"Political Value" bangsa Indonesia adalah poltik berdasarkan nilai-nilai Pancasila atau konsepsi dari Politik Pancasila, untuk membentuk struktur pemikiran politik yang didasarkan pada pandangan nilai-nilai Pancasila maka perlu dibangkitkan lagi keyakinan akan kebenaran dan keluhuran nilai-nilai Pancasila bagibangsa Indonesia. Keyakinan akan harmoisnya bangsa Indonesia dengan Pancasila merupakan sebuah impian dari nilai Pancasila dan juga terbukti menjaga harmonsasi kehidupan politik di Indonesia. Liberalisme mampumengguncang dunia menanmkan pegaruhnya ke berbagai negara tetapi negara Indonesia dala sejarah tetap mampu menjaga Pancasila dan mengatasi paham liberalism, komunisme mampu memecahbelah suatu suku bangsa dan berpegaruh keberbagai belahan dunia tetapi paham itu pada akhirnya tunduk di sebuah negara yang berideologi Pancasila.Contoh saja komunisme dan liberalisme memecah bangsa korea yang pada hakikatnya satu saudara menjadi kondisi yang saling bermusuhan. Tetapi dua idelogi besar dunia itu tidakmampu menghancurkan nilai-nilai Pancasila yang dianut oleh bangsa Indonesia. Sehingga Indonesia tidak bisa disebut sebagai negara liberalis tidakpula sebagai negara komunis tetapimerupakan negara yang berdiri datas alsafah dan jati diri dan budaya bangsanya sediri yaitu Pancasila.Ini membuktikan secara fakta historis dua ideologi besar dunia tiakmampumenundukkan bumi Nusantara.

Hal ini menunjukkan bahwa strturr pemikiran yang terwujud dalam sikap dan prilaku politik berdasarkan nilai Pancasila itu benar-benar tumbuh dalam struktur pemikiran poltik politisi bangsa Indonesia, benar-benar ada dan benar-benar nyata, Dan Politik Pancasila secara filosofis memang benar-benar menjadi jalan kebijaksanaan bagi politisi bangsa Indonesia.Tetai akhr-akhir para pelajar, para 
politisi dan pelaku-pelakupolitiklainyya yang belajar tentang politik dan bergerakserta menaruh perhatia ada politik lebih membenarkan berdasarkan fakta politik yang ada saat ini, di mana fakta politik dipengaruholeh teori-teori politik yang jauh dariprasyarat moral.oeh karena itu untuk membangun setruktur politikPancasila dalam pemikiran para politisi dan pelaku politik harus mampu mengisi struktur pemikiran akan nilai-nilai Pancasila yang secara fakta politis syarat dengan moral dan mampu tumbuh dipemikiran para politisi bangsa Indonesia yang memiliki jiwa nasinalisme. Kunikan fakta politis berdasarkan Pancasila memang sagat sulit untuk disandarkan pada logka berpikir yang erujuk pada teori-teori politik yang terkenal saat ini.banyak para pakar yang memaksaan keragka berpikir berdasar teori politik luar untuk menjelaskan secara ilmiah tentang Pancasila. Untuk membangun dan melestarikan Nilai-nilai Pancasila dalam membangun setruktur pemikiran dalam diri para politisi maka perlu sebuah keberanian memunculkan adanya teori politik yang unikan beda dari yang lainnya. Kritikan, sinisme dan berbagai hujatan tajam baik yang dilontarkan secara ilmiah harus dapat disanggah pula bahwa Politik Pncasila adalah sebuah fakta politik di bumi Nusantara yang mampu menundukkan dua ideologi besar dunia yang mana negara-negara besar terpengaruh oleh konsep dan teori politiknya yang mana di dalamnya terdapat ajaran-ajaran yang sangat objektif hanya berdasarkan fakta tetapi tidak mngindahkan pentngnya dasar moralitas.

Generasi saat ini, para politisi sekarang ersikap kurang yakin akan fakta yang menunjukkan bahwa terdapat sebuah teori-teori baru yang akan muncul dari sebuah nilai-nilai budaya bangsa Indonesia yang disebut dengan Pancasila.Keyakinan akan kebenaran dan eksistensi nilai Pancasila dan fakta-fata politis bangsa Indonesia akan ideologi negaranya hendaknya dapat menjadi modal besar oleh para politisi untkmempraktikkan Politik Pancasila.Apabila poltisi dalam strktur pemikirannya dan keyakinannya diliputi oleh daya rasa serta daya piker yang tinggi akan Pancasila, hal ini akan mendorong keluar teori-teori politik yang mengindahkan moral dari dalam pikiran para politisi, keyakinan yang begitu kuat serta menolak segala realitas politik yang tidak sesuai dengan Politik Pancasila, akan membawa politik memiliki makna yang sesungguhnya sebagai ilmu yang menjunjung tinggi harkat dan martabat kemansiaan dan moralias.dengan demkian dapat digaris bawahi bahwa untuk mewujudkan "political Value" Bangsa Indonesia para politisi harus mampu menyingkirkan teori-teori politik yang masuk dalam kelompok teori yang megindahkan atau tidak menganngap penting akhlak dar dalam pemikirannnya, dengan tetap bertahan menolak segala realitas politik yang membenarkan fakta politik pada kelompok teori yang mengabaikan moral atau akhlak.sehingga muncul warna politik dalam arti yang positif.

Penataan struktur pemahaman politik Pancasila yang ditempatkan di atas pada struktur teori-teori politik yang mengindahkan moral akan mampu memberika kekuatan pada politisi untuk membatasi bahkan menganulir teori tersebut keluar ari struktur pemikirannya atau menahan dari sikap dan perwujudannya. Sehingga yang mncul adalah sikapdan prilaku berdasar PoltikPancasila.

\section{SIMPULAN}

Berdasarkan paparan di atas maka dapat diambil sebuah kesimpulan

1. Bahwa Political action tidak selalu berbanding lurus dengan political value,dalam realitasnya di dunia politik keenderungan nilai-nilai yang bersandar pada politicalaction yang mengarah pada pragmatisme dan tujuan jangka pendek memiliki tarikan yang cukup besarmendominasi strukturpemikiran politik para politisi sehingga politik mendapatkan makna negatif.

2. Bahwa saat ini teori-teori politik berdasarkan fakta politik yang mengarah pada pragmatism dan tjuan janka pendek memiliki ruang gerakyang lebih leluasa dan subur dalam pemikiran yang membangun struktur politik para politisi.Sehingga 
teor-teori politik yang mengindahkan moral lebih subur dibandingkan dengan teori-teori politik yang syarat dengan moral

Maka dari simpulan tersebut dapat dijelaskan bahwa Perlu ada penguatan dengan berbagai bentuk kegiatan yang mampu menumbuh suburkan teori-teori politik yang syarat dengan moral dan akhlak. Dan Perlu ada upaya pembangunan struktur pemikiran politik para politisi untuk menguatkan Politik Pancasila dari dampak negatif teori-teoripolitik yang mengabaikan dasar moral melalui berbagai program, berbagai bentuk kegiatan pendidikan, pelatihan, kebijakan,pendirian organisasi atau lembaga badan dan berbagai bentuk aktivitas yang bersingungan dengan para politisi yang dapat mendorong ke arah implemntatif politik Pancasila.

DAFTAR PUSTAKA

Abdillah, Masykuri. (2013). "Hubungan agama dan negara dalam konteks modernisasi politik di era reformasi." AHKAM: Jurnal IImu Syariah 13.2

Azis, Asmaeny Dasar Negara: Hubungan Pancasila, Marhaenisme, Marxisme dan Kapitalisme dalam Skema Politik Indonesia RUAS Media Surabaya

Harrison, L. (2009). Metodologi Penelitian Politik. Jakarta : Kencana

Sanusi, Aris Riswandi, and Cecep Darmawan. (2016) "Implementasi pendidikan politik dalam membentuk karakter kepemimpinan lintas budaya pada generasi muda demi mewujudkan budaya politik pancasila (Studi deskriptif terhadap organisasi kepemudaan Gerakan Pemuda Ansor Jawa Barat)." Jurnal Pendidikan IImu Sosial 25.1 24-40.

Soelistyo, Liem Tony Dwi. (2019) "DASAR NEGARA: Hubungan Pancasila, Marhaenisme, Marxisme dan Kapitalisme dalam Skema Politik Indonesia." Mimbar Keadilan $12.1: 278227$.

Sunny, Ismail, "Menegakkan Prinsip Konstitusi", dalam Denny J.A. (ed.), Menegakkan Demokrasi, Jakarta: Kelompok Studi Indonesia.

https://nasional.kompas.com/read/2020/09/30/11223141/kpk-catat-397-pejabat-politikterjerat-korupsi-sejak-2004-hingga-mei-2020

https://www.google.com/search?q=angka+korupsi+politisi+di+Indonesia\&oq=angka+ko rupsi+politisi+di+Indonesia\&aqs=chrome..69i57.19451j0j4\&sourceid=chrome\&ie= UTF-8 